\title{
A meta-analysis of genetic and environmental factors impacting on obesity
}

\author{
AGATA KOPINIAK, ${ }^{1}$ EWA RĘBACZ-MARON ${ }^{2}$ \\ ${ }^{1}$ Student of biology at the Wrocław University of Environmental and Life Sciences \\ ${ }^{2}$ University of Szczecin, Department of Vertebrate Zoology and Anthropology, Institute for Research on Biodiversity, Faculty of \\ Biology, ul. Wąska 13, 71-415 Szczecin, Poland, e-mail: rebae@univ.szczecin.pl
}

Keywords

Abstract obesity, environmental factors, civilization diseases, genetic factors

Background: excess body weight in the populations of both developed and developing countries has been a health, social and economic issue for more than 30 years. The causes of overweight and obesity are complex and rooted in many different factors. The reasons why people gain weight need to be explored to prevent obesity-related diseases, to improve the quality of life and health status in the populations. Aim: to discuss genetic and environmental factors impacting on obesity. Materials and methods: a literature-based meta-analysis. Results: various factors contributing to excessive weight gain need to be explored; obesity prevention measures should include health-promoting education, changing eating habits in families as well as recipes and menu options in catering, and also by encouraging sports activity at every ontogenetic stage. Patients with genetic susceptibility to obesity should be supported in prophylaxis through education, elimination measures (diet) and the necessary pharmacological management so that they can remain active and independent for as long as possible. Conclusions: overweight and obesity are now a global problem. In only two generations, health complications due to excess adiposity have become hard to ignore. The process is parallel to the progress of civilisation, with the related stress, processed food, lack of exercise, insufficient sleep. Today, people have access to many modern conveniences in everyday life, and therefore more time for leisure, but still, maintaining normal (healthy) weight is becoming increasingly difficult.

\section{Metaanaliza czynników genetycznych i środowiskowych wpływających na otyłość}

Słowa kluczowe otyłość, czynniki środowiskowe, choroby cywilizacyjne, czynniki genetyczne

Streszczenie Tlo: nadmierna masa ciała mieszkańców państw rozwiniętych i rozwijających się jest problemem zdrowotnym, społecznym i ekonomicznym od ponad 30 lat. Przyczyny nadwagi i otyłości są złożone i mają niejedno podłoże. Należy szukać powodów tycia w celu zapobiegania chorobom powiązanych z otyłością, aby podnieść jakość życia i stan zdrowia społeczeństw. Cel: omówienie czynników genetycznych i środowiskowych mających wpływ na otyłość. Materiał i metoda: metaanaliza na podstawie piśmiennictwa. Wyniki: należy szukać przyczyn nadmiernego tycia na różnych aspektach; zapobiegać otyłości poprzez informację prozdrowotną, zmianę nawyków żywieniowych w rodzinach, w żywieniu zbiorowym, a także zachęcać do działań prosportowych na każdym etapie ontogenezy. Pacjentów z otyłością uwarunkowaną 
genetycznie należy wspierać w profilaktyce poprzez edukację, działania eliminacyjne (dieta) i konieczne leczenie farmakologiczne, tak aby chorzy jak najdłużej byli aktywni i samodzielni. Podsumowanie: nadwaga i otyłość to obecnie problem ogólnoświatowy. Zaledwie w ciągu dwóch pokoleń notuje się powikłania zdrowotne z powodu nadmiernego otłuszczenia. Proces ten jest równoległy z rozwojem cywilizacyjnym, związanym z nim stresem, przetworzoną żywnością, brakiem ruchu, zbyt małą ilością snu. Obecnie ludzie dysponują technicznymi udogodnieniami w życiu codziennym, a przez to mają więcej wolnego czasu, a mimo to utrzymanie prawidłowej (zdrowej) masy ciała jest coraz trudniejsze.

\section{Introduction}

According to the World Health Organisation (WHO) obesity is defined as excessive fat accumulation that may present a risk to health. Since 1975, there has been a threefold increase in the prevalence of overweight and obesity, which is now considered to be an epidemic of the 21 st century. Obesity is a medical, social and economic issue, leading directly to approx. 13\% of premature deaths regardless of sex or skin colour, and its management accounts for between $2 \%$ and $7 \%$ of healthcare spending in European countries (Wąsowski et al., 2013).

The roots of obesity are still an object of study. Research on the underlying causes of overweight and obesity has currently moved into the field of molecular genetics, as the impact of genetic factors on its development is increasingly recognised. Without the knowledge of various factors contributing to excess body weight, it cannot be effectively countered and treated.

One anthropometric measure of normal body weight is BMI (Body Mass Index). BMI = body weight $[\mathrm{kg}] /$ height $[\mathrm{m}]^{2}$. BMI scores are interpreted as follows: BMI $<16.00$ indicates grade 3 thinness; BMI 16.00-16.99 indicates grade 2 thinness; BMI 17.00-18.49 indicates grade 1 thinness; BMI 18.50-24.99 is the normal (healthy) range; BMI 25.00-29.99 indicates grade 1 overweight; BMI 30.00-39.99 indicates grade 2 overweight; BMI $40.00 \geq$ indicates grade 3 overweight (Physical status: WHO, 1995).

According to WHO data, in 2016 as many as 39\% of men and women aged 18 and older were overweight. Countries with the highest percentage of the population having BMI scores in excess of $30 \mathrm{~kg} / \mathrm{m}^{2}$ include: the USA (36.2\%), Saudi Arabia (35.4\%), Libya (32.5\%), Turkey (32.1\%), Egypt (32.0\%), Iraq (30.4\%).

In order to mitigate the adverse consequences of excessive adiposity on human life and health, it is necessary to undertake measures aimed at reducing the body weight in obese individuals.

The aim of this paper is to discuss the genetic and environmental factors impacting on obesity based on the available literature.

\section{Classification of obesity in clinical practice according to its causes}

A. Simple (primary, common) obesity, which is caused by energy surplus, that is caloric intake which exceeds the body's needs for metabolic processes and energy expenditure related to physical activity. The underlying causes of this type of obesity are primarily environmental; excessive consumption of highly processed and calorie-dense foods, with very high levels of animal fats and simple carbohydrates, plus the lack of physical activity.

B. Secondary obesity, presenting in the course of such endocrine disorders as: hypothyroidism, Cushing's disease and Cushing's syndrome, growth hormone deficiency, hypogonadism and some genetic conditions: Prader-Willi syndrome, Lawrence-Moon-Biedl syndrome, Turner syndrome, Klinefelter syndrome, as well as hypothalamic dysfunction in the course of degenerative diseases, 
inflammatory conditions, developmental defects, tumours, injuries of the central nervous system and as a result of prolonged use of certain medication, such as: corticosteroids, antidepressants and antiepileptic drugs.

\section{Based on anthropometric tests}

The abdominal type (central adiposity, android fat distribution, pot belly, apple shape) - with fat accumulating around the abdominal area. It is associated with an increased risk of cardiovascular complications, metabolic syndrome and certain types of cancer.

Gynoid or peripheral obesity, pear shape - where excess fat accumulates in the buttocks, hips and thighs. This type develops in women going through puberty, signalling hormonal health and fertility (Szymocha et al., 2009).

Certain anthropometric measures are useful in determining the type of body fat distribution, namely WC and WHR:

- Waist circumference, WC - indicates normal body weight when $\mathrm{WC}<80 \mathrm{~cm}$ (women), and $\mathrm{WC}<94 \mathrm{~cm}$ (men); the overweight range is $\mathrm{WC}=80$ to $88 \mathrm{~cm}$ (women), and $\mathrm{WC}=94$ to $102 \mathrm{~cm}$ (men); and obesity when WC $>88 \mathrm{~cm}$ (women), and $\mathrm{WC}>102 \mathrm{~cm}$ (men).

- The waist-to-hip ratio (WHR); in women WHR should not exceed 0.8 , and should preferably amount to 0.7 , while in men the optimal WHR is 0.95 and the ratio should not exceed 1.0 .

\section{Environmental factors responsible for the development of obesity}

\section{Highly processed food}

The most common contributing factor is the consumption of too much highly processed, calorie-dense foods. Also, portion sizes tend to be larger now than they used to. People tend to eat more snacks, like cakes, sweets or chocolate bars, which are composed predominantly of fat and sugar and are therefore rich in calories. On a daily basis, no more than $50-55 \%$ of the calorie intake should come from carbohydrates. What is more, simple sugars, which are present in sweets and sugary beverages, should account for no more than $10 \%$ of the daily energy intake (Białkowska, 2011). Cakes, chocolate, sweets or wafers are rich in sucrose and have little nutritional value other than being calorie-dense. Consequently, excessive consumption of carbohydrate-rich products promotes obesity.

The consumption of easily digestible carbohydrates has also surged in recent years. The increase is mainly in the consumption of energy drinks and sweetened juices. To reduce production costs, the extra sugar often comes from glucose-fructose syrup, which is relatively about $40 \%$ sweeter than sucrose. Excessive consumption of fructose leads to adverse metabolic effects, potentially contributing to elevated blood levels of very low-density lipoprotein (VLDL) and triglycerides. This process results in fatty liver (hepatic steatosis).

Excessive fructose consumption was found to be associated with arterial hypertension in young people (Nguyen et al., 2009). Drinks containing fructose promote the development of type 2 diabetes. There have been cases of young people dying from an overdose of energy drinks, especially following intensive physical exercise. 


\section{Fats}

Too much fat in the diet is another factor contributing to the development of obesity. There is a relationship between the amount of fat consumed and BMI scores (Białkowska, Szostak, 2010). Fat is a high-calorie food and requires much less energy to convert into the fat reserve compared to the conversion of carbohydrates. Digested fat is used by cells as a source of energy and as a building material of fatty compounds, cellular membranes, hormones, etc.

What matters is not only the quantity, but also the quality of fat in the diet. Usually, animal-source foods contain large quantities of saturated fatty acids and cholesterol. Animal fat stimulates appetite and leads to adverse metabolic effects, resulting in the premature development of atherosclerosis. In the development of this disease, the type of fat eaten is crucially important. Another essential factor is the balance of polyunsaturated omega- 3 to omega- 6 fatty acids. Excess amounts of dietary fat significantly increase the energy-density of one's diet. A fat-rich diet with insufficient amounts of fibre will lead to weight gain and increase appetite.

\section{Calcium}

Insufficient supply of calcium also contributes to the development of obesity. Studies show that calcium intake is associated with body mass index. A lower calcium content in the diet corresponds to an increased risk of overweight. It has also been demonstrated that higher calcium consumption (up to $1000 \mathrm{mg} / \mathrm{d}$ ) coupled with a reduced calorie intake helps achieve faster weight loss (Zemel, 2005). Dietary calcium participates in the blood coagulation process, plays a role in the function of the nervous and muscular systems, as well as regulates energy metabolism by influencing the metabolism of adipocytes, thermogenesis and lipolysis. Insufficient amounts of calcium in the diet contribute to the accumulation of lipids within fat cells (adipocytes), as a result of inhibiting lipolysis in fatty tissue (Major et al., 2008). Increased consumption of calcium may help reduce weight gain and accumulation of fat in adipocytes by stimulating lipolysis (Zemel, 2003; Van Loan, 2009).

\section{Physical activity}

Little or no physical activity is another factor which has been confirmed as a contributor to obesity. Physical inactivity is implicated not only in the development of obesity, but also in other chronic conditions. It has been demonstrated that if a lifestyle marked by no physical activity is adopted in adolescence, it tends to persist in adulthood. According to a 2017 study by Wojciech Zgliczyński, one in eight children in Poland is obese or overweight (Zgliczyński, 2017). Factors contributing to this state of affairs include widespread avoidance of physical education classes in school and spending too much leisure time at the computer and/or television. According to a survey conducted by the National Food and Nutrition Institute in Warsaw, the time spent by young people between the ages of 11 and 15 in front of the computer and television on average exceeds 4 hours a day.

Regular physical activity effectively prevents the development of obesity and many other conditions such as: diabetes (type 2), arterial hypertension, osteoporosis, cancer, and even depression. Physical activity is also helpful in the treatment of obesity and prevents excessive accumulation of fatty tissue in the body. The benefits of increased physical activity include: fat loss, increased muscle and bone mass, reversal of the undesirable decrease in resting energy expenditure caused by a bad diet, reduction of elevated insulin levels, improved glucose tolerance and lipid profile, 
improved fitness, reduction of resting and exercise blood pressure and heart rate, easier long-term maintenance of a dietary regime, improvement of general well-being and mental health; improvement of emotional state, including reduction of depressive moods and anxiety (Brownell, Wadden, 1999; van Baak, Saris, 1999).

\section{Medication}

Some medicines not only contribute to the development of obesity, but also make it harder to treat. Medication groups impacting on obesity include: progestogens, psychoactive and antidepressant drugs, serotonin antagonists, certain antihistamine, anti-allergy and antidiabetic medicines as well as steroids (Zahorska-Markiewicz, 2009). Obesity may result from changes in the anatomy of tissues and organs, e.g. abnormal hypothalamic function due to brain tumours, trauma, or inflammatory conditions.

Obesity may be caused by various endocrine disorders, related to hormone deficiency or excess. These include: Cushing's disease, hypothyroidism, pseudohypoparathyroidism, hyperprolactinemia, growth hormone deficiency, hypogonadism, polycystic ovary syndrome, insulinoma (insulin-secreting tumour, islet cell carcinoma).

\section{Psycho-emotional factors}

Psycho-emotional factors also play a role in the development of obesity. Currently, the lifestyles in many communities are characterised by high levels of stress and a fast pace. To cope with that, people consume large amounts of high-energy foods, alcoholic beverages, energy drinks, abuse nicotine and medication. An unbalanced diet is very often accompanied by little or no physical activity. Stress leads to an increased secretion of cortisol by affecting the hypothalamicpituitary-adrenal axis (Bose et al., 2009). These factors contribute to the development of central adiposity, which may in consequence lead to the development of atherosclerosis later in life.

Interestingly, central adiposity did not seem to affect previous generations. This can be observed in old photographs and films. Even if the people in them were "heavier built", they were unlikely to carry a pot belly. Most likely, the reason for fat accumulation in the visceral cavity among the industrialised populations lies in stress, fast-paced lifestyles and even air pollution (Henneberg, Grantham, 2014).

With the progress of science, researchers from many different fields turned their attention to the psychological determinants of obesity. These include: failing mechanisms of self-regulation, individual beliefs and expectations, personality traits and problems coping with stress and emotions (Ogińska-Bulik, 2007). A person suffering from self-regulation disorders loses control over the amount of consumed food, which leads to "overfeeding".

Many scholars believe that stress and inability to cope with problems are the main causes of overeating. The so-called emotional eating is a form of a coping mechanism, distracting the person from painful experiences, and a way of avoiding threats or compensating for distress (Pietrzykowska, Wierusz-Wysocka, 2008). As food is now easily accessible, for many people it is the easiest and most effective way of dealing with tension. The increased appetite is a consequence of negative emotions, discomfort and depressed mood (Stice et al., 2005).

Consumption of carbohydrates soothes negative emotions by increasing serotonin levels, which in turn improves mood. Unfortunately, carbohydrates only have a temporary effect, the bad mood returns very quickly, and the person reaches for sweets again. A vicious circle is created, which may lead to the binge eating disorder or eating anarchy. 


\section{Insomnia}

Insomnia contributes to the development of obesity. Eating disorders caused by sleep problems, e.g. the night eating disorder (NES) and sleep-related eating disorder (SRED), may cause weight gain. Symptoms of SRED are found in people who wake up in the night and eat large amounts of high-calorie food. The disorder differs from NES in that sufferers of the former have no memory of eating at night.

The night eating syndrome is diagnosed in people who are sleepless at least 3 nights a week, and who become "ravenously hungry" after 7 p.m. and eat more than $50 \%$ of their daily food ration at that time. Patients eat small portions throughout the night, they take no pleasure in eating, but feel compelled to do it nonetheless (Jakuszkowiak, Cubała, 2003). NES patients can be observed to have metabolic disorders related to the reduced secretion of leptin and melatonin, and increased release of ghrelin, galanin and cortisol (Stunkard, Allison, 2003).

There is a relationship between sleep duration and susceptibility to weight gain. Inadequate sleep disturbs the levels of ghrelin and leptin, and increases cravings for high-energy processed foods (Gangwisch et al., 2005).

\section{Vitamin D}

Another factor impacting on obesity is vitamin D deficiency. There are several reasons for vitamin D deficiency in obese individuals, and one of them is insufficient synthesis in the skin. Skin synthesis is the main source of endogenous vitamin D, accounting for approx. $80 \%$ of vitamin D supply in the body. Provitamin D3 is produced in the skin as a result of exposure to UVB radiation. Vitamin D3, otherwise known as cholecalciferol, undergoing enzymatic hydroxylation processes in the liver and kidneys, is converted to calcitriol - an active vitamin D metabolite. Calcitriol stabilises a number of processes and metabolic changes by interacting with the membrane and nuclear receptor. To date, there is no clear answer as to the causes of vitamin $\mathrm{D}$ deficiency - insufficient exposure to solar radiation or impairment of the skin synthesis process (Wąsowski et al., 2012).

According to Kull et al. inadequate skin synthesis is the likely cause for vitamin D deficiency in obese individuals. Their study involved 367 participants. The authors proved that sunbathing results in higher concentrations of calcifediol in the serum (Kull et al., 2009). In turn, Florez et al. (2007) demonstrated that obese individuals who exercise outdoors are $47 \%$ less likely to have hypovitaminosis D compared to those with obesity who exercise indoors (Florez et al., 2007). It is worth highlighting that people who do not get much exercise, spend a lot of time indoors and avoid going outside are more likely to suffer from depression.

Yvonne Foss claims that vitamin D deficiency in the obese causes the body to switch to the so-called "winter metabolism" (Foss, 2009). The intensity of sunlight decreases in the autumn, which in turn slows down metabolism and results in weight gain due to the accumulation of fat.

\section{Intestinal flora (microbiota)}

An unhealthy gut flora has been confirmed to be involved in the onset of obesity. The human gastrointestinal tract is inhabited by approx. 1,000 species of bacteria. Depending on the section of the intestine, the numbers vary greatly. The composition of the microbiota is likewise varied: the small intestine contains predominantly gram-negative aerobes, whereas the large intestine contains both gram-positive and gram-negative bacteria. $98 \%$ of the intestinal bacteria belong to 
the genera Bacteroides and Firmicutes (Żak-Gołąb et al., 2014). The role of commensal bacteria in the gastrointestinal tract has not been fully explained to date. They are known to be involved in the fermentation of undigested foods and the absorption of electrolytes, to take part in the growth and maturation of erythrocytes and epithelial cells of the large intestine, to affect the immune function and gastrointestinal motility, to participate in the synthesis of vitamins and degradation of toxins and carcinogens.

Both human and animal studies have shown that the Bacteroides to Firmicutes ratio is altered in obese individuals - with increased numbers of Firmicutes. Weight loss contributes to increasing the ratio of Bacteroides in the gut flora, pro-rata to the number of kilograms lost (Ley et al., 2006). The findings of Furet et al. indicate that this is due to changes in the diet and reduced caloric intake, rather than the weight loss itself (Furet, 2010). Despite the studies, it is still not known why the obese have relatively more Firmicutes in the gut flora. It is believed that Firmicutes thrive in those eating a typical Western diet, rich in fats and sugars (Mosley, 2017). It was also observed that a low-carbohydrate, low-fat diet leads to an increased number of Bacteroides colonies in feces.

\section{Genetic factors responsible for the development of obesity}

\section{Monogenic obesity}

To date, more than 200 cases of single-gene mutation obesity have been described. Mutations affect at least 11 genes; they are inherited according to Mendelian rules and the majority involve the melanocortin receptor 4 (Rankinen et al., 2006). Experimental studies into the genetics of obesity had started already in the mid-20th century, mainly on mice with significant hereditary obesity. Thanks to those studies, it was later possible to identify analogous irregularities in human genes and discover the key hypothalamic mechanisms governing appetite and satiety. Knowledge of these mechanisms made it possible to understand how obesity develops in individuals with defects along the pathway regulating eating behaviour.

\section{Mutations in the leptin gene and leptin receptor gene}

Leptin is an adipokine, and is also referred to as the "satiety hormone". Its gene was first cloned in mice and then in humans. It plays an important role in the hypothalamic appetite control, participates in regulating bone mass, is involved in the regulation of the immune system and the reproductive function. Up until recently, the mutation in the leptin receptor gene (LEPR) was considered rare, but innovative studies carried out in many different countries attracted additional attention to the phenomenon (Farooqi et al., 2007). It is an autosomal recessive inherited disease. A LEPR mutation accounted for $3 \%$ of the severely obese individuals examined as part of the study.

Leptin deficiency, which is caused not only by insufficient leptin, but also a defect in its receptor, presents with a similar clinical phenotype. It is characterised by high-grade obesity with the onset in the first months of life, and accumulation of excess fat in the trunk and limbs (Farooqi et al., 2002). Patients present with extreme hyperphagia (excessive hunger) which causes behavioural changes, with the affected individuals constantly seeking food and behaving aggressively when the food is restricted. Obesity is mainly due to the excessive caloric intake, as the basal metabolic rate is not dependent on leptin concentration. One important clinical finding for patients with LEPR mutation is that there is no specific difference in the severity 
of hyperlectinemia compared to other obese individuals. Earlier, it had seemed to be typical for patients with a receptor defect, but recent studies have shown this characteristic not to be of key importance (Męczekalski et al., 2008).

Carriers of the LEP/LEPR mutation do not exhibit the phenotype typical for homozygotes, but they show increased levels of adiposity. In patients with a LEP mutation, adipokine supplementation provides satisfactory results. It remedies all of their symptoms, suppressing appetite, which makes it possible to shed the excess kilograms, restore normal immune function and regulate the function of the pituitary-gonadal axis (Heymsfield et al., 2006).

\section{Mutations of the melanocortin-4 receptor (MC4R)}

Melanocortin plays a key role in the regulation of appetite by the hypothalamus. It is a ligand binding mainly to type $4 \mathrm{MSH}$ receptor. To date, more than 90 mutations have been described, of the frameshift or missense type (Yeo et al., 1998; Vaisse, 1998). The most common monogenic form of obesity is that related to an MC4R defect. According to studies, mutations in this gene are responsible for $2.4-4.0 \%$ of severe obesity cases, where BMI exceeds 35 or $40\left[\mathrm{~kg} / \mathrm{m}^{2}\right]$. It is the most common autosomal dominant disorder (Alharbi et al., 2007). A 2007 study led to the discovery of a mutation involving constant activation of MC4R, causing severe obesity. Apart from obesity, patients presented a wide range of phenotypes. Where hyperphagia used to be regarded as ubiquitous, it was found not to affect all patients (Dubern et al., 2007; Lubrano-Berthelier et al., 2006). The mutation can only be diagnosed by molecular tests. No effective therapy has been developed to date (Xiang et al., 2007).

\section{Syndromic obesity}

Obesity can be concomitant with order disorders, i.e. intellectual disability or organ dysfunction within a single clinical phenotype. Such syndromes have a genetic background and may be due to defects in more than one gene, though this is not a rule.

\section{Prader-Willi syndrome}

Prader-Willi syndrome (PWS) is the most common and long-known genetically mediated disorder related to obesity. The first case was described back in the 19th century. Ledbetter et al., (1982) linked the syndrome to a chromosomal aberration, however no specific mechanisms have been discovered to date which are responsible for the symptoms presenting in the syndrome (Ledbetter et al., 1982).

Genetically, the syndrome results from a deletion in the paternal copy of chromosome 15 in the 15q11-q13 region or a uniparental 15 disomy, where both copies of the chromosome originate from the mother. Occasionally, the syndrome may be caused by an unbalanced translocation or an imprinting defect. In 2006, Varela et al. discovered that the characteristic phenotypic expression of Prader-Willi syndrome is also present in cases involving a deletion in the region that includes the SIM1 gene (Varela et al., 2006). The syndrome is characterised by a number of anomalies. Symptoms vary depending on the individual and calendar age. Mental development is often normal, without cognitive deficit. In turn, motor development is delayed. Patients struggle with intense cravings for food, which leads to behavioural changes such as: aggression if food is withheld or stealing food. Individuals with Prader-Willi syndrome present with numerous endocrinopathies, e.g. hyperinsulinemia, hypogonadism secondary to hypothalamic dysfunction 
with underdeveloped reproductive organs, and growth hormone deficiency which results in short stature. The molecular pathogenesis of the syndrome has not been fully explained. On the other hand, the genes included in the defective region of chromosome 15 are known. Some products of those genes (NDN, MAGEL2) are strongly expressed in the central nervous system, specifically in the hypothalamus and this is the probable cause for many dysfunctions, including obesity (Muscatelli et al., 2000; Lee et al., 2000).

New whole-genome studies have led to the discovery of numerous genes involved in the development of obesity, whose expression is abnormal in Prader-Willi syndrome (ADI, POR2, MC2R, HCRT, OXTR) (Bittel et al., 2007). Complications secondary to obesity (type 2 diabetes, venous thrombosis, cardiovascular disease) are some of the more common causes for premature death in patients with the syndrome.

\section{Polygenic obesity}

Obesity with a polygenic basis is not very well understood. Many genes occurring in the population are polymorphic and lead to a tendency to accumulate excess fat in favourable circumstances (Męczekalski et al., 2008). It was observed that the genes involved in the pathogenesis of monogenic obesity also participate in the pathogenesis of polygenic obesity. Many genes are confirmed to be implicated in both types of obesity, albeit with a different extent of gene deficiency.

\section{PPAR $\gamma$ - peroxisome proliferator-activated receptor gamma $[\gamma]$}

PPAR $\gamma$ are transcriptional factors belonging to the nuclear receptor superfamily and, by regulating the expression of many genes involved in adipogenesis, metabolism of carbohydrates and lipids as well as adipokine synthesis, they are implicated in various metabolic disorders including obesity, insulin resistance and hypertension (Chmielewska-Kassassir et al., 2013). Studies focusing on PPAR $\gamma$ isoform 2 revealed that SNP at position 115 (Pro111Gln) of this receptor is associated with obesity risk, and at position 12 (Pro12Ala) with the risk of obesity and type 2 diabetes (Deeb et al., 1998; Franks et al., 2007). It was found that SNP in this location affects body weight depending on the type of diet: in the comparison of groups eating a low-fat vs. high-fat diet, the carriers of the alanine variant showed no differences in BMI increase, whereas homozygotes with prolin on a high-fat diet put on weight (Memisoglu et al., 2003). Looking back at that study, one may observe the importance of the interplay between genes and the environment in the development of polygenic obesity. The tendency to gain weight is determined by genes, but its phenotypic expression depends on environmental factors (physical activity, dietary composition in terms of quality and quantity).

\section{Endocannabinoid system and CNR1 gene polymorphisms}

Hemp (Cannabis sativa) is a herbaceous plant which has been used in folk medicine for many years. Numerous studies have been devoted to exploring its chemical composition and properties. Analyses aimed at understanding the mechanism of cannabinoid action led to the discovery of the first cannabinoid receptor (CB). A hypothesis was formulated that animal and human bodies contain substances which have similar properties to cannabinoids of plant origin and which are responsible for activating CB receptors. The hypothesis was confirmed when in 1992 the first of the endogenous ligands for the CB receptors was identified (Begg et al., 2005). 
The endocannabinoid system (ECS) is composed of $\mathrm{CB} 1$ and $\mathrm{CB} 2$ receptors, belonging to the family of 7-transmembrane receptors, non-CB1 and non-CB2 receptors, ligands for those receptors and enzymes involved in the synthesis, uptake and degradation of those ligands (Komorowski, Stępień, 2007). The ECS plays an important role in modulating energy balance. It influences hunger regulation by the central nervous system. CB1 receptors are found in the hypothalamus and are responsible for appetite stimulation, related to the starvation response (Harrold, Williams, 2003; Kirkham, 2005). Activation of the CB receptor stimulates appetite and has an antiemetic, analgesic and sedative effect (Di Marzo, Matias, 2005).

By 2011, scholars managed to sequence 1973 polymorphisms of individual nucleotides in the CNR1 gene. Studies conducted in American, European, Chinese and Japanese populations demonstrated that CNR1 gene polymorphisms are associated with body weight, fat distribution, energy expenditure and metabolic disorders.

A study in a Swiss cohort of 865 obese men showed a relationship between polymorphism in rs806381 G-allele of the CNR1 gene and polymorphism in rs2023239 T-allele vs. BMI scores (Benzinou et al., 2008). Similarly, in a French cohort a relationship was found between polymorphism in rs806381 G-allele of the CNR1 gene and BMI scores (Benzinou et al., 2008).

\section{Aberrant thermogenin (UCP1) expression}

There two main types of human adipose tissue: white adipose tissue (WAT) and brown adipose tissue (BAT). WAT and BAT differ in terms of morphology, function and anatomical location. The key function of white adipose tissue is to store energy in the form of triacylglycerols, while brown adipose tissue is involved in the regulation of non-shivering thermogenesis (Saely et al., 2012). Non-shivering thermogenesis provides for temperature regulation in warm-blooded animals. WAT and BAT also importantly differ in the number of mitochondria and the structure of mitochondrial membranes (Saely et al., 2012). Mitochondria are much more abundant in BAT cells. The inner membrane of those mitochondria contains a protein - thermogenin (UCP1), which is directly responsible for generating energy in the form of heat (Nicholls, Locke 1984; Wijers et al., 2009). Thermogenin is regarded as a marker of brown adipose tissue (Wójcik, 2011).

Thermogenin - uncoupling protein (UCP1) belongs to the group of transport proteins. Genes encoding UCP1 and adrenergic receptors have been associated with an increased susceptibility to gain weight (Stosio et al., 2016). The first polymorphism of the UCP1 gene to be described involved an adenine to guanine change at position 3826 upstream of the TATA box, in the promoter region (A-3826G, rs1800592) (Cassard-Doulcier et al., 1996). This polymorphism does not play a key role in the pathogenesis of obesity, but it was found that replacing an A-allele with a G-allele favours weight gain. Other polymorphisms which may be associated with obesity include: A-1766G polymorphism (rs3811791) at the 5' flanking region (Kim et al., 2005) and nonsynonymous polymorphism Ala64Thr (rs45539933), where $\mathrm{G}$ is replaced with A at +1068 in exon 2 of the UCP1 gene (Jia et al., 2010).

Dysfunction of the $\beta 3$-adrenergic receptor has an adverse effect on UCP1. The Trp64Arg polymorphism in $\beta 3$-adrenergic receptor was studied and found to affect the protein-receptor interaction, and to demonstrate a synergic effect with A-3826G polymorphism (Clement et al., 1996).

Oppert et al., (1994) conducted the first study which confirmed the existence of A-3826G polymorphism. Their findings proved that the presence of the G-allele was related to increased body weight (Oppert et al., 1994). In turn, a study by Kogure et al. (1998) demonstrated that 
individuals with a G-allele at the polymorphic site A-3826G burn even $200 \mathrm{kcal} /$ day less than those without the mutation (Kogure et al., 1998). The study conducted in a group of obese Japanese confirmed that carriers of the G-allele found it harder to lose weight.

\section{IgG-mediated food allergy}

The mechanism of the IgG-mediated food hypersensitivity involves the human body recognising food particles as potentially harmful foreign bodies. In IgG-mediated food allergy, incompletely digested food particles continually enter the bloodstream through the intestinal lining, which means that the concentration of immune complexes is high. These complexes travel through the bloodstream, spreading the inflammation process to new tissues and organs. This can lead to numerous health conditions, e.g. obesity and type 2 diabetes (Gałęcka et al., 2013; Zawisza, 2010; Bartuzi, 2009). The likely immediate cause of the intolerance is a compromised intestinal barrier, with larger gaps between enterocytes. Increased intestinal permeability is most commonly related to a history of infections: viral, bacterial, parasitic; exposure to environmental toxins, physical and mental stress, influence of alcohol, medication and a diet rich in preservatives and dyes (Brodzicki, 2006).

Upon exposure to a food allergen which is an integral part of the diet the inflammation process becomes chronic and leads to organ and system dysfunctions (Gałęcka et al., 2013). Characteristically, IgG-mediated allergy causes a delayed response, occurring from 8 to 72 hours after ingesting the allergen. Some scholars hypothesised that there is a link between IgG-mediated food hypersensitivity, generating a free-radical state and cytokin production, and the accumulation of adipose tissue in the body (Frank et al., 2014). Clinical dieticians believe that the right course of action in order to lose excess weight is to test for IgG-mediated food hypersensitivities and then start appropriate dietary treatment.

A chronic inflammatory response is characterised by elevated levels of inflammatory mediators, primarily TNF- $\alpha$, CRP and proinflammatory interleukins. This may lead to the development of insulin resistance and, consequently, type 2 diabetes. TNF- $\alpha$ is produced in the cells of the immune system as well as adipocytes and muscle cells. The level of TNF- $\alpha$ increases in proportion to the amount of body fat. It is responsible for adverse metabolic changes and inhibits insulin receptor function by reducing receptor phosphorylation (Moller, 2000). Seen as insulin cannot bind to its blocked receptor, its production increases, leading to the development of hyperglycaemia and hyperinsulinemia. Blood glucose levels remain high, despite the fact that the glucose is not used in metabolic processes but merely accumulated in the muscles in the form of fatty acids. This leads to changes in body composition, increasing the body fat percentage and leading to obesity (Lorenzo et al., 2008; Nieto-Vazquez et al., 2008). Enhanced secretion of TNF- $\alpha$ causes damage to leptin receptors, disrupting the hunger inhibition response.

Erlinger et al. (2003) conducted a study in which they proved that an elimination diet has a different effect on weight loss in those whose obesity is related to a persistent chronic inflammation. Inflammatory conditions reduce the effectiveness of the elimination diet and increase the risk of cardiovascular disease (Erlinger et al., 2003).

Wilders-Trusching et al. (2008) conducted a study in which they proved a link between the level of IgG antibodies and CRP in obese children. They demonstrated that obese children have significantly higher IgG antibody values (Wilders-Trusching et al., 2008). 


\section{Conclusions}

Year by year the number of obese people in the world is growing. In highly developed countries, obesity is an increasingly problematic health, social and economic issue. Regarded as a civilisation threat, it may in the future reach pandemic proportions. Eating just a few extra calories on a regular basis may in the long run add up to weight gain.

The development of obesity may be attributed to a multitude of environmental factors, associated mainly with the contemporary lifestyle, with its unlimited access to processed and calorie-dense food. Today's eating habits provide for larger portions and too many portions, without maintaining adequate intervals between meals, coupled with the wrong quantity and quality of nutrients from the diet. The habit of snacking in between meals has become the norm, due to the easy accessibility of food (Jakuszkowiak, Cubała, 2004). It is also worrying that obesity affects more and more children who give up physical activity and spend their spare time in front of the computer. Such a lifestyle is characteristic of many communities experiencing high levels of stress and a fast-paced life. The inability to cope with problems leads to overeating.

Genetic factors, including single-gene and multifactorial mutations, also play a part in the development of obesity. Genetic research started in the mid-20th century and helped prove that obesity genes can be inherited according to Mendelian rules. The most extensively studied PraderWilli syndrome is a classic example of a monogenic mutation. Polygenic obesity is not yet fully understood. In light of the prevalence of polygenic obesity, however, the diagnostics and treatment of such patients is of crucial importance. In favourable circumstances, polymorphism manifests itself in a tendency to accumulate excess fat.

The earlier the onset of obesity, the higher the prevalence of its related complications. It has been proven that obesity is implicated in increased mortality and is a risk factor for the development of diseases affecting the cardiovascular, nervous, immune and endocrine systems.

\section{References}

Alharbi, K.K., Spanakis, E., Tan, K. (2007). Prevalence and functionality of paucimorphic and private MC4R mutations in a large, unselected European British population, scanned by meltMADGE. $\mathrm{Hu}$ man Mutation, 28 (3), 294-302.

Bartuzi, Z. (2009). Alergia na pokarmy u dorosłych w praktyce lekarskiej. Postepy Dermatologii i Alergologii, XXVI (5), 385-387.

Begg, M., Pacher, P., Batkai, S. Osei-Hyiaman, D., Offertáler, L., Ming Mo, F., Liu, J., Kunos, G. (2005). Evidence for novel cannabinoid receptors. Pharmacology \& Therapeutics, 106, 133-145.

Benzinou, M., Chevre, J.C., Ward, K. Lecoeur, C., Dina, C., Lobbens, S., Durand, E., Delplanque, J. (2008). Endocannabinoid receptor 1 gene variations increase risk for obesity and modulate body mass index in European populations. Human Molecular Genetics, 17, 1916-1921.

Białkowska, M., Szostak, W.B. (2010). Żywienie w otyłości. In: M. Grzymisławski, J. Gawęcki (eds.), Żywienie czlowieka zdrowego i chorego (pp. 332-345). Warszawa: Wydawnictwo Naukowe PWN.

Białkowska, M. (2011). Etiopatogeneza Otyłości. Postępy Nauk Medycznych, 9 (XXIV), 765-769.

Bittel, D.C., Kibiryeva, N., Sell, S.M., Strong, TV., Butler, M.G. (2007). Whole genome microarray analysis of gene expression in Prader-Willi syndrome. American Journal of Medical Genetics. Part A, 143 (5), $430-442$. 
Bose, M., Olivián, B., Laferrère, B. (2009). Stress and obesity: the role of the hypothalamic-pituitary-adrenal axis in metabolic disease. Current Opinion in Endocrinology, Diabetes and Obesity, 16 (5), $340-346$.

Brodzicki, J. (2006). Przepuszczalność jelitowa-temat wart zainteresowania. Pediatria Współczesna. Gastroenterologia, Hepatologia i Żywienie Dziecka, 8 (3), 188-191.

Brownell, K.D., Wadden, T.A. (1999). The LEARN Program for Weight Control. Dallas: American Health Publishing Company.

Cassard-Doulcier, A.M., Bouillaud, F., Chagnon, M., Gelly, C., Dionne, F.T., Oppert, J.M., Bouchard, C., Chagnon, Y., Ricquier, D. (1996). The Bcl I polymorphism of the human uncoupling protein (ucp) gene is due to a point mutation in the 5'-flanking region. International Journal Obesity Relatet Metabolic Disorders, 20, 278-279.

Chmielewska-Kassassir, M., Woźniak, L., Ogrodniczek, P. Wójcik, M. (2013). Rola receptorów aktywowanych przez proliferatory peroksysomów $\gamma(\mathrm{PPAR} \gamma) \mathrm{w}$ otyłości i insulinooporności. Postepy Higieny i Medycyny Doświadczalnej, 67, 1283-1299.

Clement, K., Ruiz, J., Cassard-Doulcier, A.M., Bouillaud, F., Ricquier, D., Basdevant, A., Guy-Grand, B., Froguel, P. (1996). Additive effect of A-->G (-3826) variant of the uncoupling protein gene and the Trp64Arg mutation of the $\beta 3$-adrenergic receptor gene on weight gain in mor- bid obesity. Int. J. Obes. Relat. Metab. Disord., 20, 1062-1066.

Deeb, S.S., Fajas, L., Nemoto, M. Pihlajamäki, J., Mykkänen, L., Kuusisto, J., Laakso, M., Fujimoto, W., Auwerx, J. (1998). A Pro12Ala substitution in PPAR2: associated with decreased receptor activity, lower body mass index and improved insulin sensitivity. Nature Genetics, 20 (3), 284-287.

Di Marzo, V., Matias, I. (2005). Endocannabinoid control of food intake and energy balance. Nature Neuroscience, $8,585-589$.

Dubern, B., Bisbis, S., Talbaoui, H. (2007). Homozygous null mutation of the melanocortin-4 receptor and severe early-onset obesity. Journal of Pediatrics, 150 (6), 613-617.

Erlinger, T.P., Miller, E.R., Charleston, J. Appel, L.J. (2003). Inflammation modifies the effects of a reducedfat low-cholesterol diet on lipids results from the DASH-dodium trial. Circulation, 108, 150-154.

Farooqi, I.S., Matarese, G., Lord, G.M. (2002). Beneficial effects of leptin on obesity, T cell hyporesponsiveness, and neuroendocrine/metabolic dysfunction of human congenital leptin deficiency. The Journal of Clinical Investigation, 110, 1093-1103.

Farooqi, I.S., Wangensteen, T., Collins, S. Kimber, W. (2007). Clinical and molecular genetic spectrum of congenital deficiency of the leptin receptor. The New England Journal Medicine, 356 (3), 237-247.

Florez, H., Martinez, R., Chacra, W., Strickman-Stein, N., Levis, S. (2007). Outdoor exercise reduces the risk of hypovitaminosis D in the obese. The Journal of Steroid Biochemistry and Molecular Biology, 3-5 (103), 679-681.

Foss, Y.J. (2009). Vitamin D deficiency is the cause of common obesity. Medical Hypotheses, 72, 314-321.

Frank, M., Szachta, P., Gałęcka, M., Ignyś, I. (2014). Alergia Pokarmowa IgG-zależna i jej znaczenie w otyłości i cukrzycy typu 2. Forum Zaburzeń Metabolicznych, 3 (5), 108-114.

Franks, P.W., Jablonski, K.A., Delahanty, L. (2007). Diabetes Prevention Program Research Group. The Pro12Ala variant at the peroxisome proliferator-activated receptor gamma gene and change in obesity-related traits in the Diabetes Prevention Program. Diabetologia, 50 (12), 2451-2460.

Furet, J.P., Kong, L.C., Tap, J., Poitou, C., Basdevant, A., Bouillot, J.L., Mariat, D., Corthier, G., Doré, J., Henegar, C., Rizkalla, S., Clément, K. (2010). Differential adaptation of human gut microbiota to bariatric surgery-induced weight loss: links with metabolic and low grade inflammation markers. Diabetes, 59, 3049-3057. 
Gałęcka, M., Szachta, P., Bartnicka, A., Cichy, W. (2013). Alergia IgG-zależna a wybrane choroby przewodu pokarmowego. Przegląd Gastroenterologiczny, 8 (4), 225-229.

Gangwisch, J., Malaspina, D., Boden-Albala, B., Heymsfield, S.B. (2005). Inadequate sleep as a risk factor for obesity: Analyses of the NHANES I. Sleep, 28 (10), 1289-1296.

Harrold, J.A., Williams, G. (2003). The canna- binoid system: a role in both the homeostatic and hedonic control of eating? British Journal of Nutrition, 90, 729-734.

Henneberg, M., Grantham, J. (2014). Obesity - a natural consequence of human evolution. Anthropological Review, 77 (1), 1-10.

Heymsfield, S.B., Fong, T.M., Gantz, I., Erondu, N. (2006). Fat and energy partitioning: longitudinal observations in leptin-treated adults homozygous for a Lep mutation. Obesity, 14 (2), 258-265.

Jakuszkowiak, K., Cubała, W.J. (2004). Zespół jedzenia nocnego - rozpowszechnienie, diagnoza i leczenie. Psychiatria, 2 (1), 107-111.

Jia, J.J., Tian, Y.B., Cao, Z.H., Tao, L.L., Zhang, X., Gao, S.Z., Ge, C.R., Lin, Q.Y., Jois, M. (2010). The polymorphisms of UCP1 genes associated with fat metabolism, obesity and diabetes. Molecular Biology Reports, 37, 1513-1522.

Kim, K.S., Cho, D.Y., Kim, Y.J., Choi, S.M., Kim, J.Y., Shin, S.U., Yoon, Y.S. (2005). The finding of new genetic polymorphism of UCP-1 A-1766G and its effects on body fat accumulation. Biochim. Biophys. Acta, 1741, 149-155.

Kirkham, T.C. (2005). Endocannabinoids in the regulation of appetite and body weight. Behavioural Pharmacology, 16, 297-313.

Kogure, A., Yoshida, T., Sakane, N., Umekawa, T., Takakura, Y., Kondo, M. (1998). Synergic effect of polymorphisms in uncoupling protein 1 and $\beta 3$-adrenergic receptor genes on weight loss in obese Japanese. Diabetologia, 41, 1399.

Komorowski, J., Stępień, H. (2007). Rola układu endokannabinoidowego w regulacji czynności dokrewnej i kontroli równowagi energetycznej człowieka. Postępy Higieny i Medycyny Doświadczalnej, 61, 99-105.

Kull, M., Kallikorm, R., Lember, M. (2009). Body mass index deter- mines sunbathing habits: implications on vitamin D levels. Internal Medicine Journal, 39, 256-258.

Ledbetter, D.H, Mascarello, J.T, Riccardi, V.M, Harper, V.D, Airhart, S.D, Strobel, R.J. (1982). Chromosome 15 abnormalities and the Prader-Willi syndrome: a follow-up report of 40 cases. American Journal of Human Genetics, 34 (2), 278-285.

Lee, S., Kozlov, S., Hernandez, L. Chamberlain, S.J. Brannan, C.I. Stewart, C.L. Wevrick, R. (2000). Expression and imprinting of MAGEL2 suggest a role in Prader-Willi syndrome and the homologous murine imprinting phenotype. Human Molecular Genetics, 9 (12), 1813-1819.

Ley, R.E., Turnbaugh, P.J., Klein, S., Gordon, J.I. (2006). Human gut microbes associated with obesity. Nature, 444, 1022-1023.

Lorenzo, M., Fernández-Veledo, S., Vila-Bedmar, R. et al. (2008). Insulin resistance induced by tumor necrosis factor-alpha in myocytes and brown adipocytes. Journal of Animal Science, 86 (14 supl.), E94-E10.

Lubrano-Berthelier, C., Dubern, B., Lacorte, J.M. (2006). Melanocortin 4 receptor mutations in a large cohort of severely obese adults: prevalence, functional classification, genotype-phenotype relationship, and lack of association with binge eating. The Journal of Clinical Endocrinology \& Metabolism, 91 (5), 1811-1818.

Major, G.C., Chaput, J.P., Ledoux, M., St-Pierre, S., Anderson, G.H., Zemel, M.B. (2008). Tremblay A. Recent developments in calcium - related obesity research. Obesity Review, 9, 428-445. 
Memisoglu, A., Hu, F.B., Hankinson, S.E. Manson, J.E., De Vivo, M., Willett, W.C., Hunter, D.J. (2003). Interaction between a peroxisome proliferator-activated receptor gamma gene polymorphism and dietary fat intake in relation to body mass. Human Molecular Genetics, 12 (22), 2923-2929.

Męczekalski, B., Czyżyk, A., Warenik-Szymankiewicz, A. (2008). Rola genów w powstawaniu otyłości. Współczesne poglądy, patogeneza, aspekty kliniczne. Endokrynologia. Otyłość i Zaburzenia Przemiany Materii, 5 (1), 27-37.

Moller, D.E. (2000). Potential role of TNF-alpha in the pathogenesis of insulin resistance and type 2 diabetes. Trends Endocrinology \& Metabolism, 11 (6), 212-217.

Mosley, M. (2017). The Clever Guts Diet. Parenting Matters.

Muscatelli, F., Abrous, D.N., Massacrier, A. Boccaccio, I., Le Moal, M., Cau, P., Cremer, H. (2000). Disruption of the mouse Necdin gene results in hypothalamic and behavioral alterations reminiscent of the human Prader-Willi syndrome. Human Molecular Genetics, 9 (20), 3101-3110.

Nguyen, S., Choi, H.K., Lustig, R.H., Chi-yuan Hsu. (2009). Sugar - Sweetened beverages, serum uric acid, and blood pressure in adolescents. Journal Pediatrics, 154, 807-813.

Nicholls, D.G., Locke, R.M. (1984). Thermogenic mechanisms in brown fat. Physiological Reviews, 64 (1), $1-64$.

Nieto-Vazquez, I., Fernández-Veledo, S., Krämer, D.K., Vila-Bedmar, R., Garcia-Guerra, L., Lorenzo, M. (2008). Insulin resistance associated to obesity: the link TNF-alpha. Archives of Physiology and Biochemistry, 114 (3), 183-194.

Obesity and overweight (2018). WHO. Retrieved from: www.who.int/news-room/fact-sheets/detail/obesity-and-overweight.

Ogińska-Bulik, N. (2007). Pułapki jedzenia. Style i Charaktery, 2, 14-16.

Oppert, J.M., Vohl, M.C., Chagnon, M., Dionne, F.T., Cassard-Doulcier, A.M., Ricquier, D., Perusse, L., Bouchard, C. (1994). DNA polymorphism in the uncoupling protein (UCP) gene and human body fat. Int. J. Obes. Relat. Metab. Disord., 18, 526-531.

Physical status: the Use and Interpretation of Anthropometry. Report of a WHO expert committee. WHO Tech Rep Ser Geneva 854 (1995), 1-452.

Pietrzykowska, E., Wierusz-Wysocka, B. (2008). Psychologiczne aspekty nadwagi, otyłości i odchudzania się. Polski Merkuriusz Lekarski, XXIV, 473-475.

Rankinen, T., Zuberi, A., Chagnon, Y.C. Weisnagel, S.J., Argyropoulos, G. Walts, B., Perusse, LB., Bouchard, C. (2006). The human obesity gene map: The 2005 Update. Obesity, 14 (4), 529-644.

Saely, C.H., Geiger, K., Drexel, H. (2012). Brown versus white adipose tissue: a mini-review. Gerontology, $58,15-23$

Stice, E., Presnell, K., Shaw, H., Rohde, P. (2005). Psychological and Behavioral Risk Factors for Obesity Onset in Adolescent Girls: A Prospective Study. Journal of Consulting and Clinical Psychology, 73 (2), 195-202.

Stosio, M., Witkowicz, A., Kowalska, A., Karabon, L. (2016). Genetyczne uwarunkowania zaburzonej ekspresji termogeniny (UCP1) w otyłości prowadzącej do zespołu metabolicznego. Postępy Higieny i Medycyny Doświadczalnej, 70, 1389-1403.

Stunkard, A.J., Allison, K.C. (2003). Two forms of disordered eating in obesity: binge eating and night eating. International Journal of Obesity, 27, 1-12.

Szymocha, M., Bryła, M., Maniecka-Bryła, I. (2009). Epidemia otyłości w XXI wieku. Zdrowie Publiczne, 119 (2), 207-212.

Vaisse, C., Clement, K., Guy-Grand, B., Froguel, P. (1998). A frameshift mutation in human MC4R is associated with a dominant form of obesity. Nature Genetics, 20, 113-114. 
van Baak, M.A., Saris, W.H.M. (1999). Exercise and Obesity. In: P.G. Kopelman, M.J. Stock (eds.), Clinical Obesity. Oxford: Blackwell Science.

Van Loan, M. (2009). The Role of Dairy Foods and Dietary Calcium in Weight Management. Journal of the American College of Nutrition, 28 (1), 120-129.

Varela, M.C., Simoes-Sato, A.Y., Kim, C.A., Bertola, D.R., De Castro, C.I., Koiffmann, C.P. (2006). A new case of interstitial 6q16.2 deletion in a patient with Prader-Willi-like phenotype and investigation of SIM1 gene deletion in 87 patients with syndromic obesity. European Journal of Medical Genetics, 49 (4), 298-305.

Wąsowski, M., Walicka, M., Marcinkowska-Suchowierska, E. (2012). Obesity - the condition predisposing to vitamin D deficiency. Postępy Nauk Medycznych, 3 (XXV), 258-264.

Wąsowski, M., Walicka, M., Marcinkowska-Suchowierska, E. (2013). Otyłość-definicja, emidemiologia, patogeneza. Postępy Nauk Medycznych, 4 (XXVI), 301-305.

Wijers, S.L., Saris, W.H., van Marken Lichtenbelt, W.D. (2009). Recent advances in adaptive thermogenesis: potential implications for the treatment of obesity. Obesity Reviews, 10, 218-226.

Wilders-Truschnig, M., Mangge, H., Lieners, C. Gruber, H.J., Mayer, C., März, W. (2008). IgG antibodies against food antigens are correlated with inflammation and intima media thickness in obese juveniles. Experimental and Clinical Endocrinology \& Diabetes, 116 (4), 241-245.

Wójcik, B. (2011). Brunatna tkanka tłuszczowa u dorosłego człowieka: występowanie i funkcja. Endokrynologia. Otyłość i Zaburzenia Przemiany Materii, 7, 34-40.

Xiang, Z., Pogozheva, I.D., Sorenson, N.B. (2007). Peptide and small molecules rescue the functional activity and agonist potency of dysfunctional human melanocortin-4 receptor polymorphisms. Biochemistry, 46 (28), 8273-8287.

Yeo, G.S., Farooqi, I.S., Aminian, S., Halsall, D.J., Stanhope, R.G., O’Rahilly, S. (1998). A frameshift mutation in MC4R associated with dominantly inherited human obesity. Nature Genetics, 20, 111-112.

Zahorska-Markiewicz, B. (2009). Zasady postępowania w otyłości. Kraków: Archi Plus.

Zawisza, E. (2010). Reakcje pokarmowe - nie mediowane IgG. Alergia, 3, 47-48.

Zemel, M.B. (2003). Role of dietary calcium and dairy products in modulating adiposity. Lipids, 38, 139146.

Zemel, M.B. (2005). The role of dairy foods in weight managements. Journal of the American College of Nutrition, 24, 5375-5465.

Zgliczyński, W.S. (2017). Nadwaga i otyłość w Polsce. Infos, 4 (227).

Żak-Gołąb, A., Olszanecka-Glinianowicz, M., Kocełak, P. (2014). Rola mikroflory jelitowej w patogenezie otyłości. Postępy Higieny i Medycyny Doświadczalnej, 68, 84-90.

Cite as: Kopiniak, A., Rębacz-Maron, E. (2018). A meta-analysis of genetic and environmental factors impacting on obesity. Acta Biologica, 25, 95-110. DOI: 10.18276/ab.2018.25-08. 